\title{
A safe, reliable and regenerative electrical energy supply to power the future
}

\author{
H. Weber and N. Ahmed \\ University of Rostock - 18059 Rostock, Germany
}

\begin{abstract}
Summary. - Today, three phenomena are developing into critical global problems, requiring urgent attention from leaders all over the world. The first of these is the increase in carbon dioxide $\left(\mathrm{CO}_{2}\right)$ emissions due to the escalated use of coal, resulting in the gradual increase of the Earth's average temperature. The second is the continually diminishing fossil fuel resources, e.g. oil and natural gas, which are the primary sources of energy for vital services like transportation and domestic heating. The third is the unforeseen and rapid "world population boom" since the beginning of the 19th century after the invention of the steam engine by James Watt. The combination of these three factors signal imminent danger. With the increase of the world population, there is a subsequent rise in the usage of both electrical and non-electrical types of energy. At the same time, not only are the sources of these energy forms, i.e. the fossil fuels, depleting because they are non-renewable but their usage is also severely detrimental to the environment. Therefore, it is of utmost importance to reduce the dependence on fossil fuels and switch to renewable or even nuclear resources as alternatives, in order to prevent an impending climate disaster. Hence, taking the aforementioned problems into account, a method is proposed in this paper to create a safe, reliable and regenerative electrical energy supply system using renewable wind and solar energy as well as hydrogen storages.
\end{abstract}

\section{1. - Introduction}

In fig. 1, a picture developed by two National Aeronautics and Space Administration (NASA) data visualizers is presented, showing the world illuminated by city lights during the night [1]. As can be seen easily, North America, Europe, Japan and South-Korea 


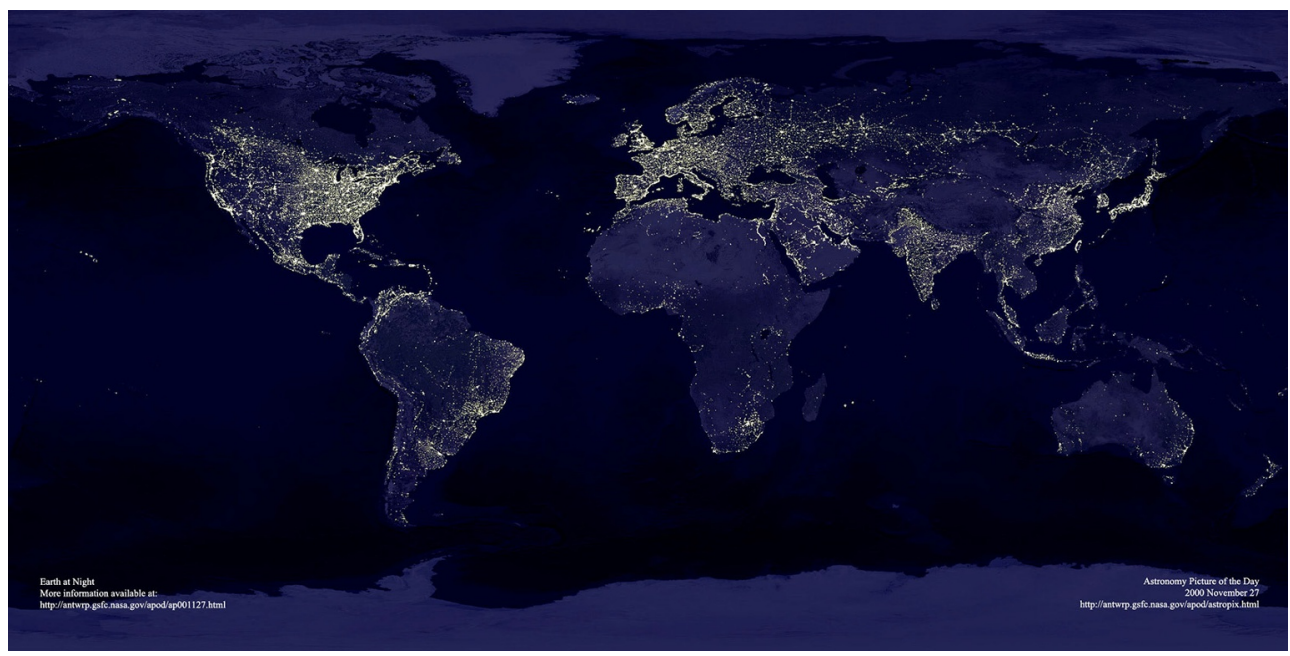

Fig. 1. - The Earth lights at night. This a composite image of hundreds of pictures made by the orbiting Defense Meteorological Satellite Program (DMSP) satellites [1].

are brightly lit. These regions are the ones with the highest standards of living. In Europe this means that a two-person household consumes approximately $3.5 \mathrm{MWh}$ of electrical energy per year [2-5]. Described in gasoline equivalents, this is roughly equal to filling a 100-liter car tank 3.5 times per year. Taking Europe's population and its total energy usage into account, an annual consumption of about $37 \mathrm{MWh}$ per capita can be calculated, as displayed in table I [6]. In the United States of America (USA) this value is approximately doubled, i.e. $78 \mathrm{MWh}$ per capita per year. This means that every

TABLE I. - Comparison of the annual energy consumption per capita between different regions of the world [6-10]. 1 toe $=11.63$ megawatt-hour $(M W h)$.

\begin{tabular}{|c|c|c|c|c|}
\hline Regions & $\begin{array}{c}\text { Energy } \\
\text { consumption } \\
\text { (million toe) }\end{array}$ & $\begin{array}{c}\text { Energy } \\
\text { consumption } \\
(\mathrm{TWh})\end{array}$ & $\begin{array}{c}\text { Population } \\
\text { (millions) }\end{array}$ & $\begin{array}{c}\text { Energy } \\
\text { consumption } \\
\text { per capita } \\
\text { (MWh) }\end{array}$ \\
\hline United States & 2188.3 & 25449.9 & 325.7 & $\mathbf{7 8 . 1}$ \\
\hline EU-28 & 1629.5 & 18951.1 & 508.5 & $\mathbf{3 7 . 3}$ \\
\hline China & 2973.3 & 34579.5 & 1390 & $\mathbf{2 4 . 8}$ \\
\hline India & 851.1 & $9,898.3$ & 1260 & $\mathbf{7 . 9}$ \\
\hline South Korea & 272.7 & 3171.5 & 49.09 & $\mathbf{6 4 . 6}$ \\
\hline Australia & 125.3 & 1457.2 & 22.25 & $\mathbf{6 5 . 5}$ \\
\hline Russia & 709.7 & 8253.3 & 144.5 & $\mathbf{5 7 . 1}$ \\
\hline Japan & 429.8 & 4998.6 & 136.7 & $\mathbf{3 6 . 6}$ \\
\hline World & 13647.4 & 158719.3 & 7383 & $\mathbf{2 1 . 5}$ \\
\hline
\end{tabular}




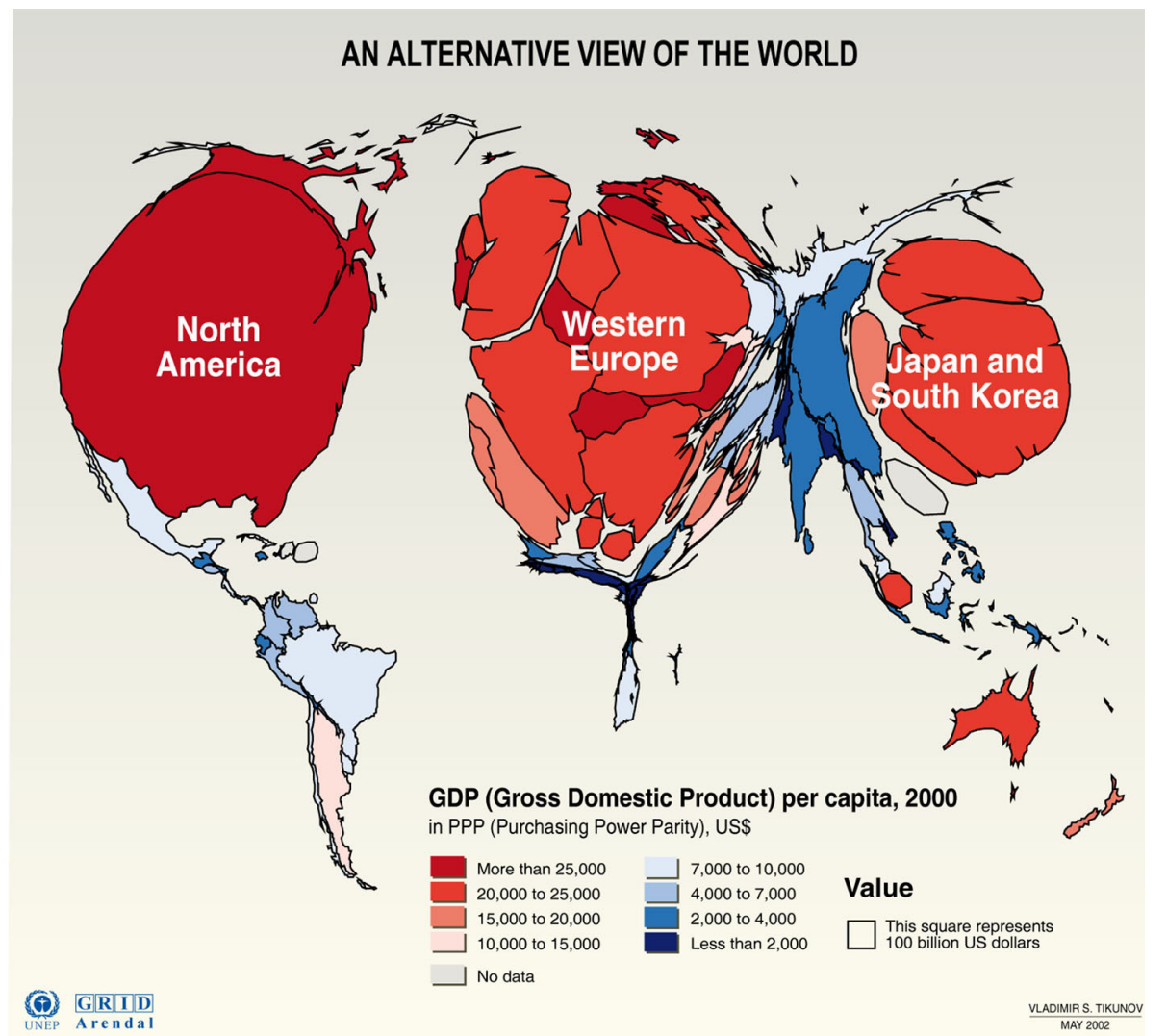

Fig. 2. - The GDP per capita of different regions of the world in Purchasing Power Parity (PPP) in the year 2000 [11].

person in the USA consumes almost twice the energy compared to a resident in Europe on an annual basis. The next largely illumined regions which can be seen on the map are China and India. These so-called "emerging nations" have increased their energy consumption drastically in the recent years, leading to annual figures of about $25 \mathrm{MWh}$ and $8 \mathrm{MWh}$ per capita, respectively.

Countries such as Russia and Australia also have high annual energy consumption per capita of roughly $57 \mathrm{MWh}$ and $66 \mathrm{MWh}$, respectively. However, only certain parts of these areas appear to be brightly lit in fig. 1 owing to their massive size and nature of the population distribution. On the contrary, regions like Africa are nearly completely dark, despite possessing a high population. This is also true for a lot of countries in South America such as Bolivia and Peru. This confirms the fact that the "Earth Night Lights" are not a reflection of the world's population distribution, but instead represent the quality of life in different areas of the world. Unpopulated regions like deserts and large forests are not taken into account in this case. 
The trends from fig. 1 are also reflected in fig. 2 which represent the Gross Domestic Product (GDP) per capita of the different regions of the world in the year 2000. Here, the sizes of the regions are adapted according to their total GDP. From this depiction, it can be observed that North America, Europe, Japan and South Korea have the highest GDP per capita values of more than US\$20000 per capita. Today, these values are much higher; greater than US\$ 50000 for North America and Australia, around US\$ 40000 for Europe and Japan and close to US\$30000 for South Korea [12]. This indicates a clear link between the electrical consumption per capita and distribution of global wealth.

\section{2. - The role of fossil fuels in global overpopulation and climate change}

When it comes to ensuring the distribution of the global wealth, one invention was of paramount importance as the driving force. As shown in fig. 3, this was the Steam Engine designed by James Watt. The Scotsman received the patent for his machine in 1769 [13]. This contributed to the onset of the first industrial revolution, a significant turning point in the human history, roughly within the next 50 years [14]. In fig. 4, the example of threshing is used to describe one of the many benefits of this invention for mankind. In the past, threshing was done manually for weeks on the farmyard and after the rise of the steam engine, the same work could be done in a matter of hours. However, not only

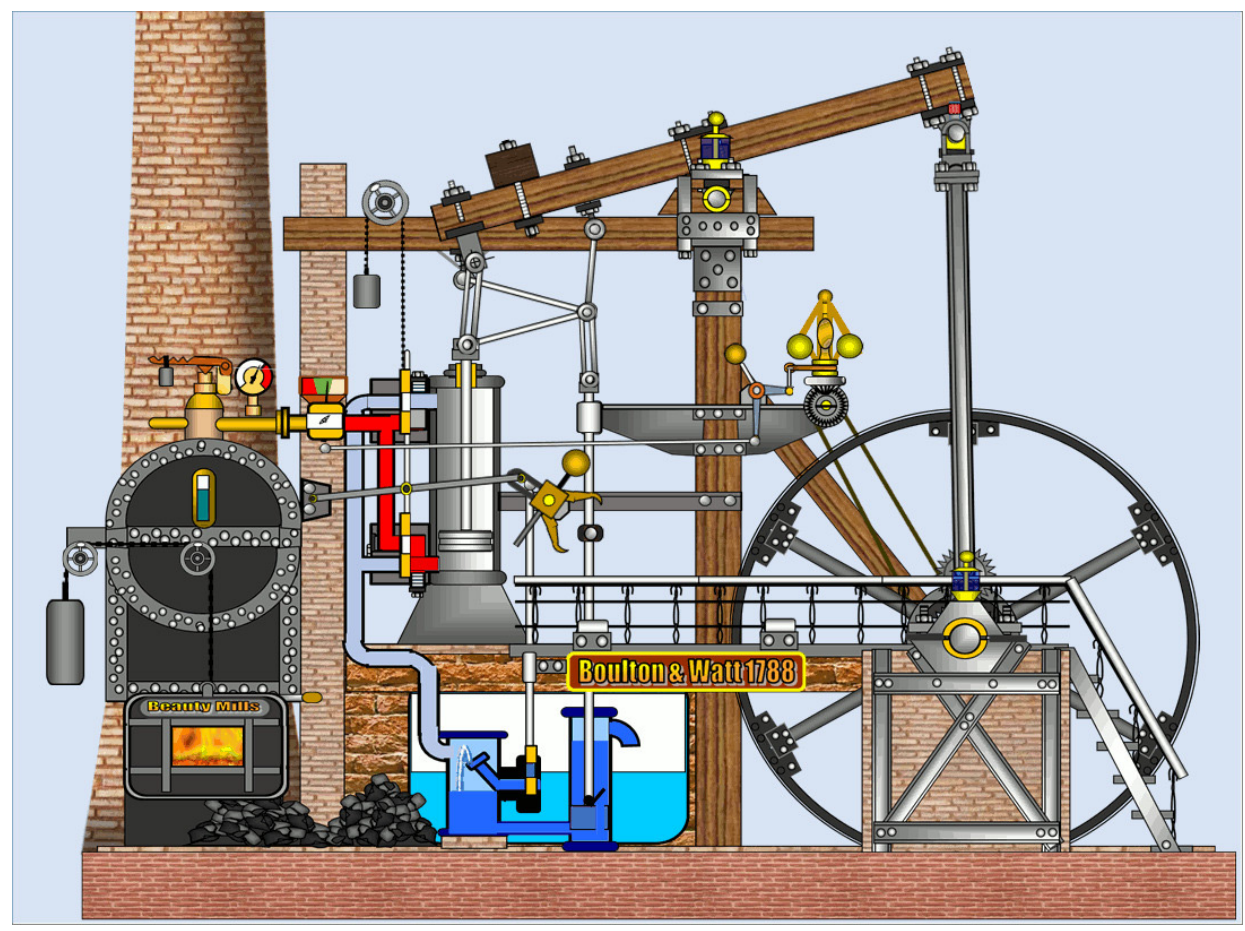

Fig. 3. - The Steam Engine of James Watt and Mathew Bolton [15]. 



Fig. 4. - Left: threshing via manual labor. Right: threshing by using a threshing machine $[16,17]$.

were farming techniques revolutionized as a result, but also transportation, irrigation, manufacturing of medical products and of course military needs experienced a dramatic boom. Heavy and daunting manual work was reduced for the working class. Then again, the cost of this, being paid till today, is the rise of two other global nightmares; the rapid increase in population and the overuse of fossil fuels resulting in the greenhouse effect leading to the gradual increase of the Earth's average temperature.

Figure 5 portrays the change in world population through time. As predicted in the diagram on the left, more than eight billion people will live on the globe in the year 2025. The primary reason for this, as exhibited in the zoomed figure on the right, is the accelerated population growth at the beginning of the 19th century. This was the time when not only were the number of steam engines increasing drastically but also operating reliably. The red arrow on the figure gives an estimate of the total world

World Population Growth Through History

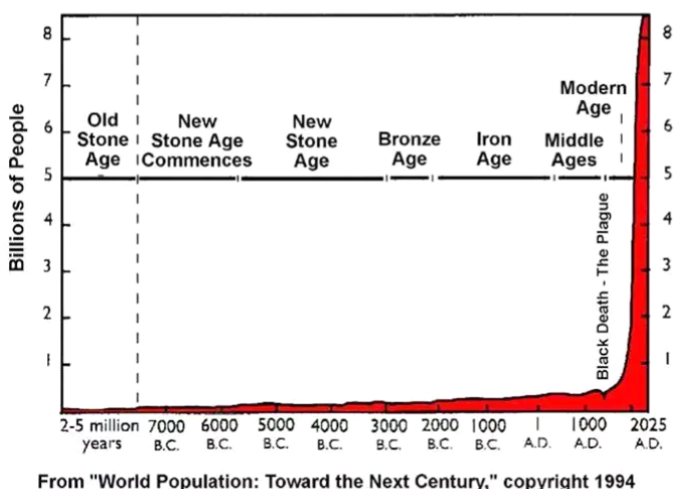

by the Population Reference Bureau

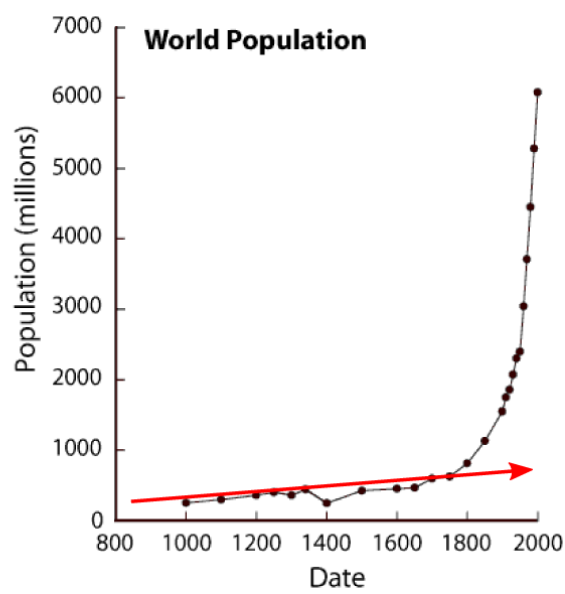

Fig. 5. - Left: world population growth through history. Right: zoomed view of the global population over the last millennium $[18,19]$. 
population without this invention. This indicates that less than one billion people would live on the planet today!

The practice of harvesting energy from fossil fuels, based on their current rate of usage, is only expected to continue for approximately 200 more years [20]. Before the inception of such extensive usage of fossil fuels, all the energy was originating from humans, animals as well as wind and water forces. After these non-renewable sources are depleted, only such traditional energy sources along with the prospect of photovoltaics (PV) and nuclear energy will be available. So in the end, the all-important question arises. How can energy be provided to the future generations? Surely, the answer to this question will play a crucial role in the continued existence of life as we know it. While searching for a possible answer, one must also anticipate the possible energy supply and demand in the future. Figure 6 displays such data representing the expected growth of electrical energy in Europe and the entire world until 2040, forecasting an increase of $8 \%$ and $61 \%$, respectively. Thus, it cannot be expected that the use of electrical energy will be reduced in the future.

Table II lists the different forms of fossil fuel reserves, their consumption rate and their predicted lifetimes. The required data was accumulated from different sources and then used to calculate the lifetime values. As can be seen, only coal is expected to exist for nearly the next 150 years. Oil, natural gas and uranium reserves could come to an end within half a century. As reserves only those fossil energy sources are considered the extraction of which are economically viable. In contradiction, fossil fuel resources such as deep grounded coal, oil sand and shale etc. are energy sources which cannot be mined easily owing to geological, economic and technological limitations. The exploration of such types of primary energy would not only be very expensive, but also environmentally detrimental. Additionally, bearing in mind the current alarming increase
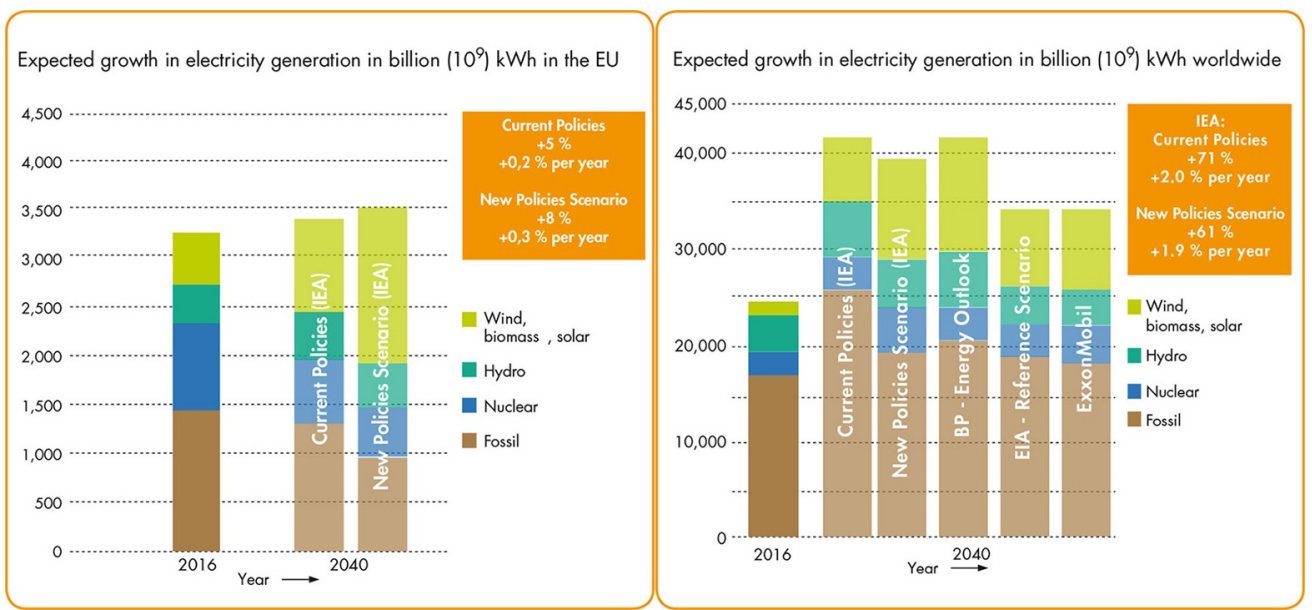

Fig. 6. - Predicted electrical energy production increase in the EU (left) and the World (right) with calculations adopted from $[21]$. 
TABLE II. - Different fossil reserves and resources along with their projected lifetimes, taking their current storage levels and rate of usage into account [22-26].

\begin{tabular}{|c|c|c|c|c|c|}
\hline \multirow{2}{*}{ Fossil fuel types } & \multicolumn{3}{|c|}{ Reserves } & \multicolumn{2}{c|}{ Resources } \\
\cline { 2 - 6 } & Storage & $\begin{array}{c}\text { Consumption } \\
\text { (per year) }\end{array}$ & $\begin{array}{c}\text { Lifetime } \\
\text { (years) }\end{array}$ & Storage & $\begin{array}{c}\text { Lifetime } \\
\text { (years) }\end{array}$ \\
\hline Coal & $1055 \mathrm{Bt}$ & $7.8 \mathrm{Bt}$ & 135 & $16195 \mathrm{Bt}$ & 2028 \\
\hline Oil & $244 \mathrm{Bt}$ & $4.66 \mathrm{Bt}$ & 52 & $161 \mathrm{Bt}$ & 38 \\
\hline Natural gas & $197 \mathrm{Tm}^{3}$ & $3.85 \mathrm{Tm}^{3}$ & 51 & $310 \mathrm{Tm}^{3}$ & 92 \\
\hline Uranium & $7.64 \mathrm{Mt}$ & $56 \mathrm{Kt}$ & 136 & $36.81 \mathrm{Mt}$ & 657 \\
\hline Non-conventional oil & - & - & - & ${ }^{*} 280 \mathrm{Bt}$ & 456 \\
\hline Non-conventional gas & - & - & - & $527 \mathrm{Tm}^{3}$ & 833 \\
\hline
\end{tabular}

* Increased value largely due to a re-evaluation of the oil shale resources [27].

in the atmospheric density of $\mathrm{CO}_{2}$, it would be best to discourage the extraction and subsequent usage of such resources.

Figure 7 (left) represents a horizontal bar chart signifying the total and per capita $\mathrm{CO}_{2}$ emissions due to the burning of fossil fuels in different regions. The percentage change in the emissions between the years 1990 and 2014 is also shown for each region. As can be seen, the largest increase is in China and India, which are home to the highest populations in the world. Only Europe has reduced its $\mathrm{CO}_{2}$ emissions by $21 \%$, while for USA, the figure is nearly unchanged (4\%). On the figure to the right, the production of $\mathrm{CO}_{2}$ from different power plant types is shown. Here of course the emission level from lignite plants is maximum, but that from natural gas power plants is also quite high. Thus, in the long run, combined cycle gas plants are the best option as power plants running on non-renewable fossil fuels. In the end though, considering the ultimate effect

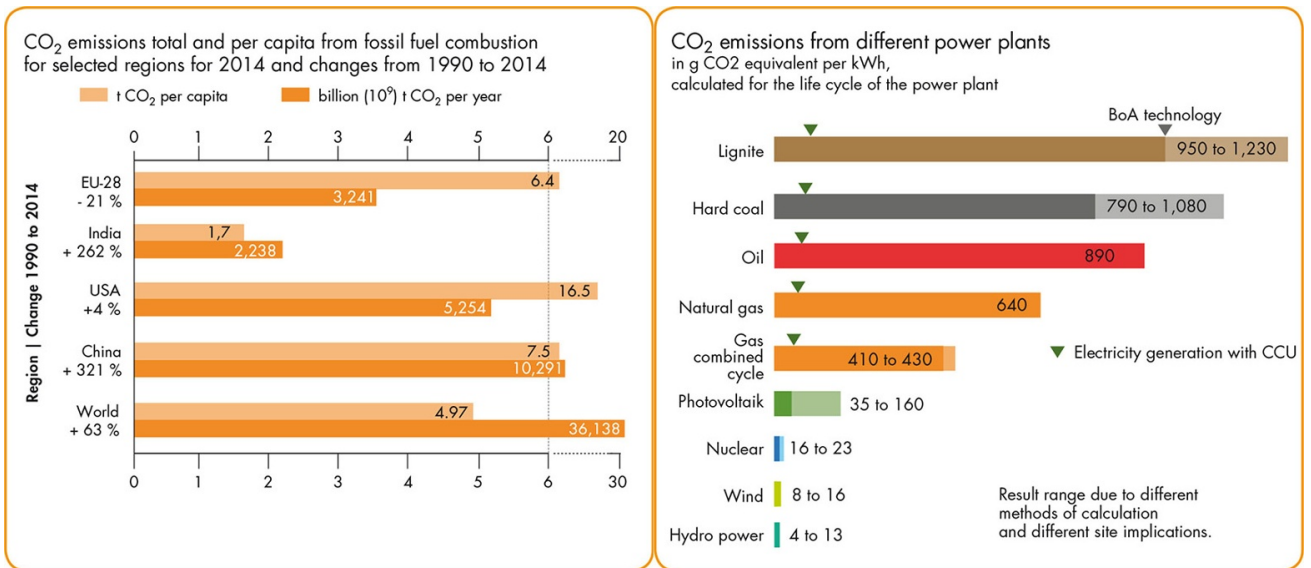

Fig. 7. - Carbon dioxide $\left(\mathrm{CO}_{2}\right)$ emissions in selected regions of the world (left) and from different types of power plants (right) [28, 29]. 
TABLE III. - Incentives, goals and future challenges for the energy sector of Germany.

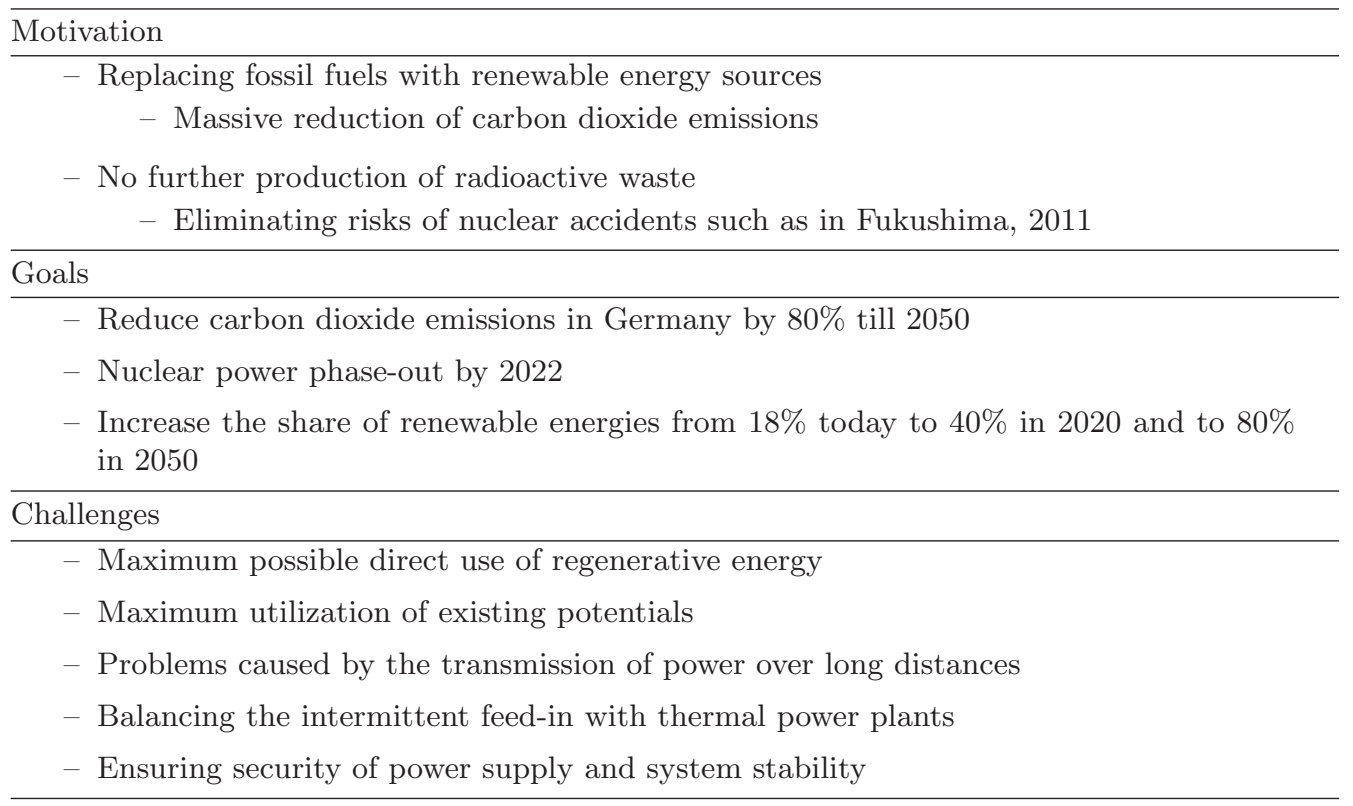

of $\mathrm{CO}_{2}$ and other greenhouse gases on the climate and environment, PV, wind, nuclear and hydropower are the best and outright options for electrical energy generation.

\section{3. - Transformation of the electrical energy system}

So taking these issues into account, the goals to be met are shown in table III, using Germany as an example. Similar targets also hold true for other countries, since solving the world's energy crisis and simultaneously tackling an impending climatic disaster requires a global effort.

\section{4. - Development of wind and solar resources in Germany}

Table IV, displays the magnitudes of electrical power and energy generation from wind and PV resources in Germany between the years 2011 and 2025. The maximum electrical load in Germany is $80 \mathrm{GW}$ and this value is expected to remain constant in the near future. On the other hand, the production of power from the renewables is projected to reach $100 \mathrm{GW}$ in 2020. As a result, a significant part of the society believes that further installations to harness renewable power are unnecessary. This often results in strong opposition towards construction of new $\mathrm{PV}$ power stations or wind farms. However, analysis regarding the electrical energy requirement for the country leads to completely different conclusions. Germany needs about $600 \mathrm{TWh}$ of electrical energy per year, but the renewable sources can only generate about $200 \mathrm{TWh}$ [30]. It is predicted that the maximum amount of energy which can be harvested from renewable resources 
TABLE IV. - Projected installed power capacity and energy output of wind and solar resources in Germany till 2025 [32].

\begin{tabular}{|c|c|c|c|c|c|c|c|c|}
\hline \multirow{3}{*}{ Year } & \multicolumn{4}{|c|}{ Power generation $(\mathrm{GW})$} & \multicolumn{4}{|c|}{ Power generation $(\mathrm{GW})$} \\
\hline & \multicolumn{2}{|c|}{ Wind } & \multirow{2}{*}{ PV } & \multirow{2}{*}{ Sum } & \multicolumn{2}{|c|}{ Wind } & \multirow{2}{*}{ PV } & \multirow{2}{*}{ Sum } \\
\hline & Onshore & Offshore & & & Onshore & Offshore & & \\
\hline 2010 & 27.2 & 0.3 & 17.0 & 44.5 & 58.0 & 1.0 & 12.0 & 71.0 \\
\hline 2011 & 28.2 & 0.8 & 23.0 & 52.0 & 61.0 & 2.8 & 24.0 & 87.8 \\
\hline 2012 & 29.8 & 1.2 & 29.0 & 60.0 & 64.6 & 3.8 & 30.5 & 98.9 \\
\hline 2013 & 31.2 & 2.3 & 32.0 & 65.5 & 67.6 & 8.4 & 33.5 & 109.5 \\
\hline 2014 & 32.3 & 3.5 & 35.0 & 70.8 & 69.2 & 13.8 & 37.0 & 120.0 \\
\hline 2015 & 33.6 & 4.4 & 38.0 & 76.0 & 72.0 & 19.8 & 39.8 & 131.6 \\
\hline 2016 & 34.1 & 6.1 & 41.2 & 81.4 & 73.0 & 26.8 & 43.2 & 143.0 \\
\hline 2017 & 34.6 & 7.7 & 44.0 & 86.3 & 75.7 & 31.3 & 46.0 & 153.0 \\
\hline 2018 & 35.6 & 10.3 & 46.4 & 92.3 & 76.3 & 42.7 & 48.7 & 167.7 \\
\hline 2019 & 36.2 & 12.0 & 49.2 & 97.4 & 79.0 & 50.0 & 51.5 & 180.5 \\
\hline 2020 & 36.9 & 14.3 & 51.9 & 103.1 & 80.0 & 59.0 & 54.3 & 193.3 \\
\hline 2021 & 37.8 & 14.8 & 53.8 & 106.4 & 81.0 & 63.0 & 56.3 & 200.3 \\
\hline 2022 & 38.2 & 17.0 & 55.5 & 110.7 & 82.0 & 72.0 & 58.2 & 212.2 \\
\hline 2023 & 38.4 & 18.8 & 57.0 & 114.2 & 83.0 & 80.8 & 59.8 & 223.6 \\
\hline 2024 & 39.0 & 20.7 & 59.0 & 118.7 & 84.0 & 87.0 & 61.8 & 232.8 \\
\hline 2025 & 39.5 & 21.7 & 60.2 & 121.4 & 84.8 & 92.0 & 63.2 & 240.0 \\
\hline
\end{tabular}

will be limited to $1000 \mathrm{TWh}$ in the country due to limitation of free space. However, the total final consumption of energy currently per year is 2600 TWh [31]. Hence, there is still a significant difference between consumption and production.

Nevertheless, basing the operation of the electrical energy supply solely on wind and solar resources is also not possible since it introduces additional problems in the electrical grid. An overview of this is presented in fig. 8. Here, the projected total consumption and corresponding generation of electrical power is shown in Germany for a duration of four weeks in May 2020 [32]. As can be seen, the power generation from resources consisting of hydropower, wind onshore and offshore, combined heat and power, as well as photovoltaics is completely unrelated to the load demand. This means that some storage power plants (SPP) are needed to bridge the gap between consumption and production.

\section{5. - Operation of a storage power plant (SPP)}

The SPP consists of converters and storages. The power plant does not contain any flywheels or rotating masses. Similar to wind turbines and solar panels, the SPP is connected to the grid via power electronic converters and hence does not have any inertia. However, in order to function effectively in the current electrical network, the 


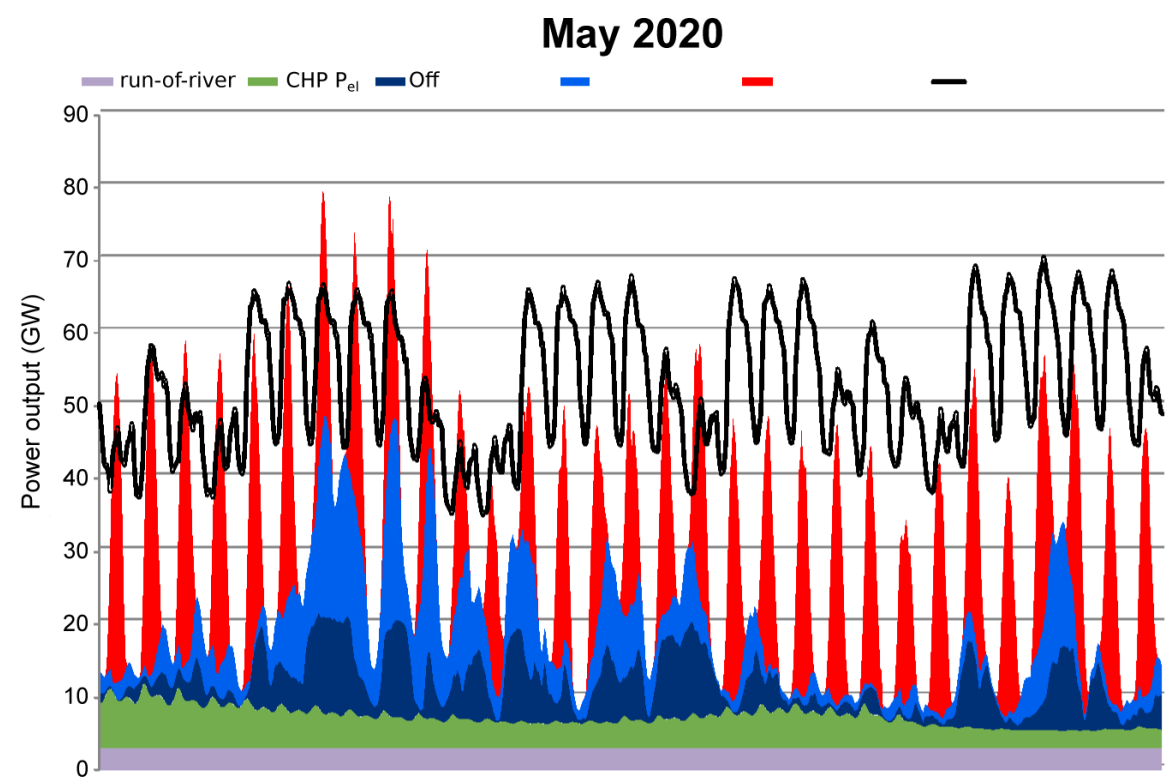

Fig. 8. - The projected electrical power demand and corresponding generation from intermittent as well as non-dispatchable sources during May 2020 [32].

SPP converter systems have to adapt to the rotating masses and respective frequency of the conventional power plants (CPP). This can be done by synthetically generating rotating inertia and primary reserve power. To achieve this, the converters have to measure the instantaneous active power at the connecting node so they can properly feed their angle-oriented regulating power into the grid. This way, these new converter systems can also function as power plants and can hence be integrated into the grid.

In the future, when the number of CPP reduces significantly in the electrical power supply due to the lack of fossil fuels, the need for such power converters to adapt to rotating masses will diminish and frequency control may become obsolete. A new method of grid control can then be introduced, known as the nodal voltage angle control [33,34]. Under this control method, the SPP can function either in grid-forming or grid-supporting mode with a constant grid frequency. All the fundamental principles of electrical energy supply and power system control, which are satisfied today with the CPP running on fossil fuels, can also be met by the SPP. An overview of this is presented in fig. 9 where the component chains of the two types of power plants are compared. The mode of operation of a SPP operating in grid-forming mode is explained next and compared with the output response of a coal fired thermal power plant, when there is a step increase in the active power requirement in the network.

Conversion/adaptation. The step increase in the active power requirement at the $\mathrm{DC} / \mathrm{AC}$ converter with a constant nodal voltage angle (grid-forming) leads to an instantaneous increase of three-phase $\mathrm{AC}$ current and therefore also an instantaneous increase of direct current on the DC side of the adjacent converter. 


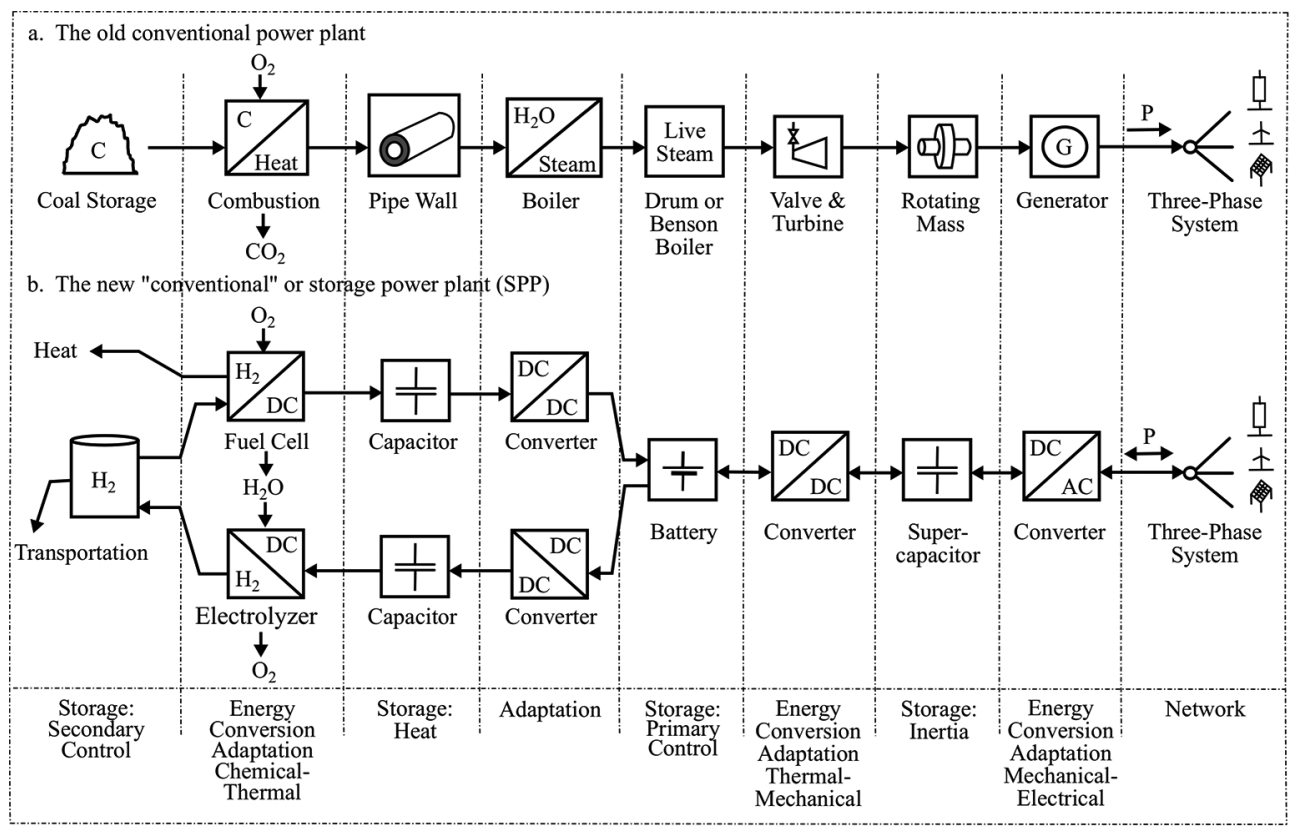

Fig. 9. - Comparison between the (a) existing fossil fuel based and (b) new storage power plant.

Storage. The supercapacitor instantaneously accesses its stored electrical energy and supplies this as output power. A capacitor is chosen for this purpose since it can immediately supply large magnitudes of power. As a result, the voltage of the supercapacitor decreases, which signifies the amount of its stored energy. These features are similar to that of the spinning reserve in a thermal power plant, which is provided by the decrease in the speed of the rotating masses in the system.

Conversion/adaptation. The downstream DC/DC converter's governor between the battery and the supercapacitor in fig. 9(b) has to keep the capacitor voltage constant. To this end, it accesses the battery increasing the battery output power within a few seconds. As a result, the supercapacitor charging current increases and this recharges its energy storage. These properties are similar to that of the primary control of thermal power plants where the opening of the steam valve in the boiler is adjusted to increase the flow of live steam, restoring the speed of the turbine prime mover.

Storage. Due to the increase in battery output power there is a decrease in battery voltage resulting in a decline in the amount of stored energy as well.

Conversion/adaptation. The DC/DC converter, on the upper branch between the fuel cell and the battery, adjusts the required voltages enabling the charging current to flow from the fuel cell to the battery. The fuel cell's control unit increases its activity and synthesizes more water from hydrogen and oxygen and as a result produces more energy to replenish the battery storage as well as satisfy the power demand in the network.

Storage. The fuel cell's control unit accesses the hydrogen storage within a few minutes and increases the fuel input mass flux. The amount of hydrogen in the storage decreases. 
It may be refilled autonomously by the plant via the electrolyzer. This is similar to secondary control in a coal fired thermal power plant where the fuel governor accesses the coal store to increase the fuel input. However, the coal storage cannot be reloaded automatically by the plant. The capacitor between the DC-DC converter and the fuel cell stores some energy and this is analogous to the heat stored on the pipe walls inside the boiler of a thermal power plant.

During steady state operation, the required power is effectively transferred from the hydrogen storage to the three-phase network. The battery or the capacitor storages only act, when the consumption or production in the network changes suddenly, to instantaneously respond and provide the necessary ancillary services autonomously. Contrary to current power plants, which are only able to reduce their output to a certain minimum, this new type of power plant can actually reverse its output. In case of a production surplus from renewable sources or decrease in load demand, there is a shock-free transition from fuel cell to electrolyzer operation to store the excess energy. The corresponding converters adjust the voltage of each component, while the electrolyzer produces hydrogen of the required pressure, which can also be used later for automobiles [35].

\section{6. - Angle regulated operation of a storage power plant}

When the power supply system will mainly rely on storage power plants, "Watt's speed control" will not be required anymore. The three-phase supply can be operated at a constant frequency, for instance at $50 \mathrm{~Hz}$. The tasks of grid control like spinning reserve and primary control can be fulfilled using the nodal voltage angle at the storage power plant's connection point. The grid itself with its admittance matrix and voltage angles operates as a coordinating unit. All the required information is provided using the given load flow. Storage power plants can operate either in grid-forming mode, as slack power plants (voltage source), or in grid-supporting mode, as PV (constant active power and voltage magnitude output) power plants (current or power source). These features are present in the current conventional power plants with a certain time delay from either an integral acting angle control (slack behavior) or active power control (PV behavior). To that end, all power plants have to know the current voltage angle at their connected terminal with reference to the $50 \mathrm{~Hz}$ angle standard of their control area via an accurate radio controlled quartz clock. This clock can be synchronized via the time signal transmitter, DCF77, of the Physikalisch-Technische Bundesanstalt (PTB) in Braunschweig, Germany once each day.

The mode of operation of this new type of grid control is best explained with an example network shown in fig. 10. The grid consists of 25 equidistant nodes, each connected to either a generator or a load. The nodes are interconnected via transmission lines, each $50 \mathrm{~km}$ long and at a voltage level of $110 \mathrm{kV}$. The line impedances are identical and each has a magnitude of $0.3 \Omega / \mathrm{km}$, with the resistance to reactance ratio being 0.1 .

There are 11 power plants, of which 5 are slack storage power plants. The other 6 are $\mathrm{PV}$ power plants, i.e. generators at terminals where the active power $(\mathrm{P})$ being supplied and the voltage magnitude $(|\mathrm{V}|)$ has a known value. The remaining 14 nodes are each 


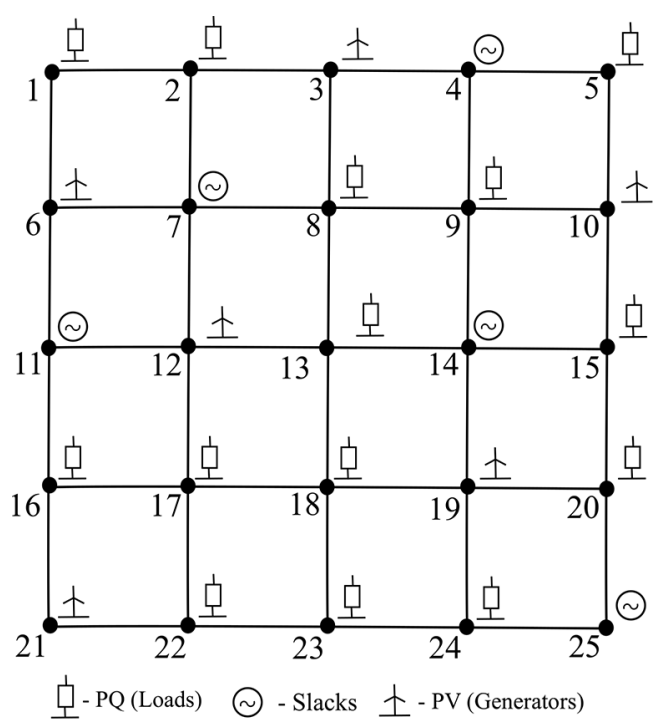

Fig. 10. - 25-node example network.

connected to a $\mathrm{PQ}$ consumer, i.e. loads at terminals where the active $(\mathrm{P})$ and reactive power $(\mathrm{Q})$ being consumed are known.

It is assumed that each of the 14 loads consumes $10 \mathrm{MW}$ of active power. The total consumption of $140 \mathrm{MW}$ is equally shared by the 5 Slacks and the $6 \mathrm{PV}$ Generators each producing 12.7 MW to meet this demand. Each load also consumes 3.33 MVAR of reactive power which is supplied later by the generators. Unfortunately, the reactive power results are not discussed here due to limitation of space. The network modeling and simulations are carried out in the software DIgSILENT PowerFactory. The slack and PV generators are modeled as AC Voltage Sources along with necessary control loops to represent the behavior of power electronic converters replacing the conventional Synchronous or Asynchronous generators.

Figures 11 and 12 (left) show the voltage phasors of the initial load flow calculations


Fig. 11. - Voltage phasors of storage power plants (left) and that of PV generators (right), after the initial loadflow. 

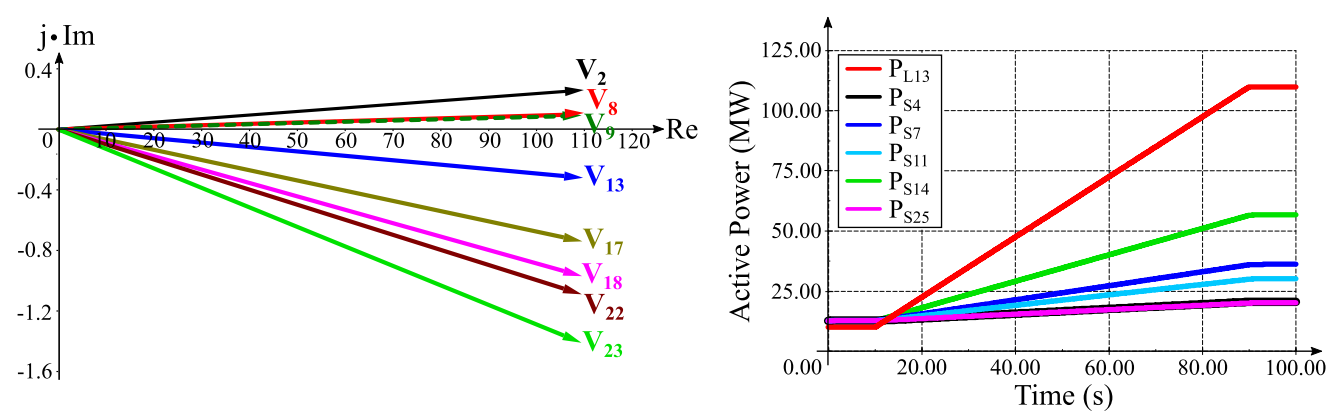

Fig. 12. - Voltage phasors of loads after the initial loadflow (left) and the active power output of the storage power plants along with the change in load power consumption (right).

respectively, for slack storage power plants, PV power plants, and PQ consumers. As shown in the diagrams, the PQ consumer's voltage phasors follow the surrounding voltage phasors of slack and PV power plants, ensuring the load flow from the generators to the consumers. For the sake of clarity in voltage angles, the imaginary axis is shown in an overstretched manner in this depiction.

In the first case of investigation with the 25 node network, a ramp is implemented at the central node 13 to represent an increase in the power consumption by load. The consumer power demand at this node is increased from $10 \mathrm{MW}$ to $110 \mathrm{MW}$ in a duration of $80 \mathrm{~s}$ and the response of the five slack storage power plants is analyzed. Figure 12 (right) shows this power increase of the consumer at node 13 and the corresponding reaction of the constant voltage slack storage power plants. The depiction shows how each of the slack storage power plants supply the additional required power according to their electrical proximity to the consumer.

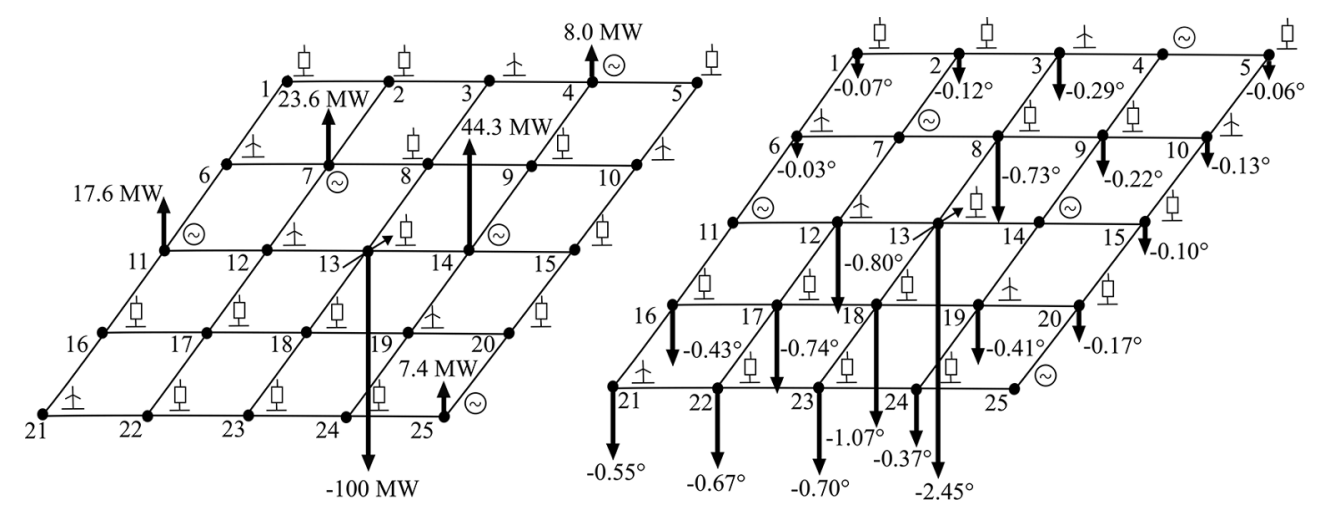

Fig. 13. - Left: increase in power consumption by load at node 13 and the resulting increases in the generation of every slack power plant. Right: angle changes in PV generators and PQ consumers during the increase in load power consumption at node 13. 


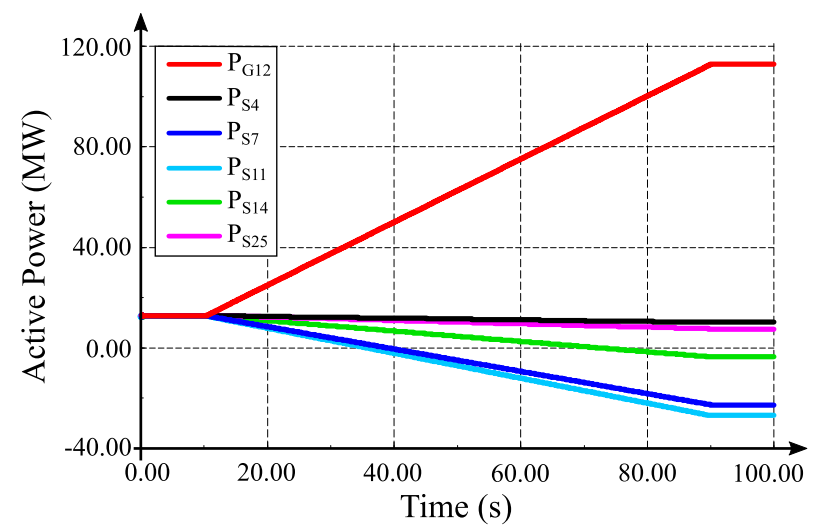

Fig. 14. - Active power of slack nodes and increasing generation at node 12 .

These results are further supported by fig. 13 (left), which shows the maximum power increases of the consumer and storage power plants, depicted as bars. Consumption is shown as a negative value, and generation as positive values. Due to the resistance in the transmission lines, there will be some losses during the power flow and the total additional power supplied will be slightly greater than the additional demand of $100 \mathrm{MW}$. Such behavior of storage power plants is analogous to the combined effect of spinning reserve and primary control. This type of primary control is load flow oriented, since the storage power plants closer to the origin of the disturbance generate more power than the remote ones. Hence, in the event of a disturbance, the load flow mainly emerges at that location while remote storage power plants contribute little in terms of power supply.

Figure 13 (right), exhibits the angular torsion of all the non-slack nodes in the investigated grid. All angular changes are depicted from their initial operating point as reference. The voltage angle of the load in node 13 has a maximum decrease by $2.45^{\circ}$ owing to the large increase in power consumption. The resulting angle torsions in the rest of the grid due to this power decrease are required by the slack power plants to provide the necessary additional power.

In the next case of investigation with the 25 node network, a ramp is implemented at node 12 containing a PV generator in order to increase the generator power output from $10 \mathrm{MW}$ to $110 \mathrm{MW}$ in a duration of $80 \mathrm{~s}$. This depicts a situation that could possibly arise from the increase in power generation of wind turbines in a particular region due to an increase in wind speed. The response of the five slack storage power plants to this change is then analyzed.

Figure 14 depicts how each of the slack storage power plants reduce their power generation or increase their power storing capability due to the generation of additional power in the system. Once again, the response of the slack storage power plants are according to their electrical proximity to the node with changing power, in this case node 12. This is also supported by fig. 15 (left). These results show that not only can slack storage power plants increase their power generation to respond to increased load demands, but they are also able to store active power if there is excessive generation 


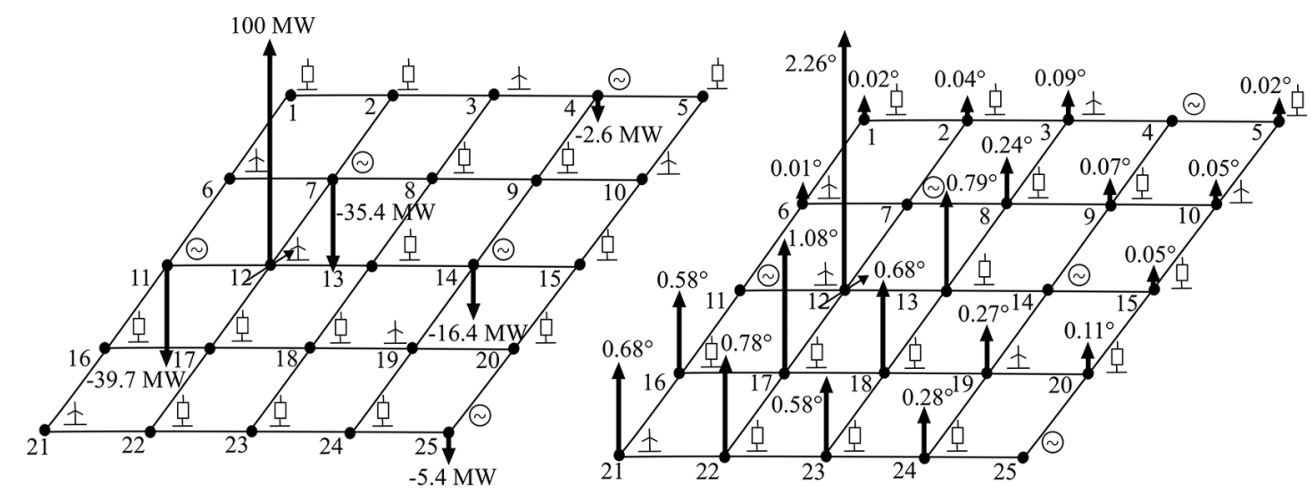

Fig. 15. - Left: increase of power production by PV generator at node 12 and the resulting decreases in the generation of every slack power plant. Right: angle changes in PV generators and PQ consumers during the increase in power generation at node 12 .

from renewable sources in the system. This truly exhibits the possibility of bidirectional active power flow for the slack storage power plant system, as shown in fig. 9(b).

Figure 15 (right), depicts all angular changes of the non-slack nodes from their initial operating point. Since the grid is organized in such a way that there are more slacks to its northern and eastern part, the angular torsions have higher values in the zones with fewer slacks, i.e. the southwestern part of the grid. The voltage angle of the generator in node 12 has a maximum increase of $2.26^{\circ}$ owing to the large increase in its power generation. The resulting angle changes in the nodes due to the power increase in node 12 are used by the slack power plants to reduce their output and accordingly store the excess energy to counter the presence of additional power in the system.

\section{7. - What could be the consequences of ignoring reason?}

From the information provided till this point, it is clear that the problems mentioned previously have to be solved not only to ensure a reliable energy supply in the future but also for the overall development of our planet. The use of fossil fuel energy resources has to be reduced and, if possible, even stopped in the future. The consumption of energy should not significantly increase any further and the growth of the world population needs to be limited. To achieve all these, it is necessary that a significant part of the younger generation is not only aware of these issues but is also able to understand them and offer possible solutions to tackle these problems.

What happens when unqualified and, in certain cases, unethical people are in charge of decisions under crisis situations can be exemplified with the incident of the "Vasa" warship sinking in the year 1628 in Stockholm, Sweden during the Thirty Years' War. To construct this ship, an equivalent amount of money close to the entire Gross Domestic Product of one year in Kingdom Sweden was used, to gain warfare advantage in the Baltic Sea against Poland. 


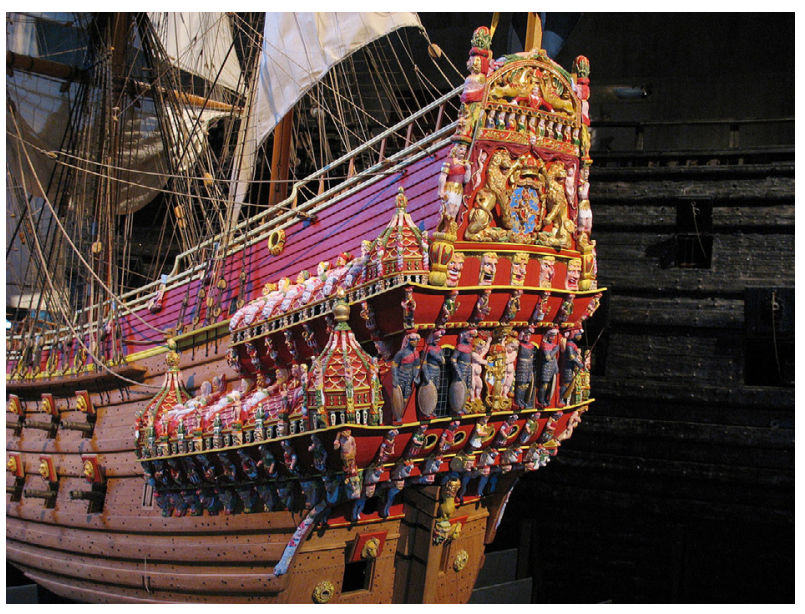

Fig. 16. - 1:10 scale model of the ship on display at the Vasa Museum [36].

In fig. 16 a model of the ship can be seen, now present in a museum in Stockholm. Initially, it was decided that the ship should only have one deck of cannons. However, King Gustav Adolf recommended to install a second set in an additional higher deck. Due to this decision, the center of mass of the warship became too high and the ship was unstable. As a result of the death of the initial Dutch constructor during the construction phase, new unskilled people took over the job. After finalizing the construction of the warship, a stability test was performed with 30 sailors running back and forth from port to starboard five to ten times. During this time, it was observed that the ship was inclining sideways beyond expected limits and thus the test was stopped. The two new contractors understood the problem and could conclude that the ship would sink
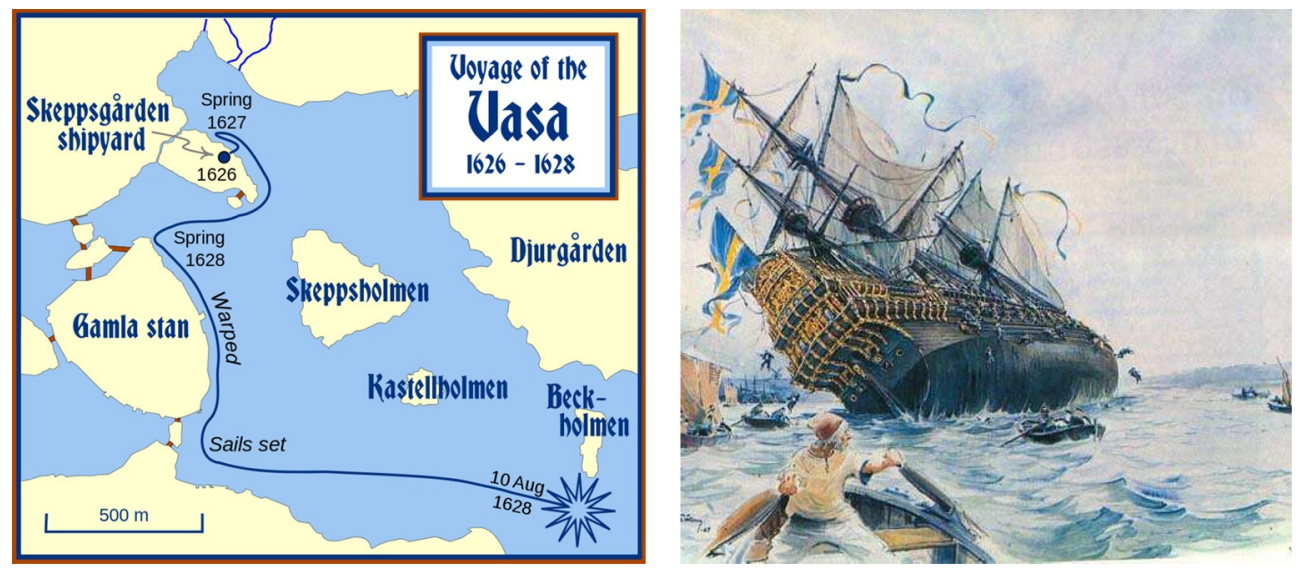

Fig. 17. - Left: the maiden journey of the Vasa. Right: the sinking of the great warship $[37,38]$. 
immediately if it was allowed to sail. However, neither of them informed the King nor did anything stop the maiden voyage. Under this situation, the only solution would have been to inform the responsible authority and dismantle the ship in order to salvage its parts so a better one could be constructed later. However, this did not happen and thus the ship started its voyage from the shipyard as can be seen in fig. 17 (left). After about 20 minutes, there was a strong gust of wind and the glamorous ship tilted sideways allowing water to flood into the open lower gundeck causing the ship to sink rapidly, as shown in fig. 17 (right).

Today, we are nearly in the same situation concerning our energy supply, $\mathrm{CO}_{2}$ emissions, global warming and the increasing global overpopulation. We know the problem, we know that the current system is unstable and we know the possible alternatives to using fossil fuels. Thus, it is completely in our own hands if we opt not to make any changes and continue in our present course or whether we decide to take action against such impending threats and give our future generations a chance to live on this planet with at least the same standards of living as ours.

\section{REFERENCES}

[1] Mayhew C. and Simmon R., (NASA/GSFC), NOAA/NGDC, DMSP Digital Archive, Astronomy Picture of the Day (Earth at Night) (Image) 2000. Retrieved from https:// apod.nasa.gov/apod/ap001127.html.

[2] Household composition statistics (2017). Retrieved from https ://ec.europa.eu/eurostat/ statistics-explained/index.php/Household_composition_statistics\# Household_size.

[3] MorRis C., German power bills are low compared to US average (Blog) 2015. Retrieved from https://energytransition.org/2015/05/german-power-bills-lowcompared-to-us/.

[4] MoRRIS C., High German power prices, low monthly bills? (Blog) 2018. Retrieved from https://energytransition.org/2018/02/high-german-power-prices-low-monthlybills/.

[5] Thalman E. and Wehrmann B., What German households pay for power, Clean Energy Wire 2019. Retrieved from https://www.cleanenergywire.org/factsheets/whatgerman-households-pay-power.

[6] Eurostat Statistics Explained, The EU in the world - energy (online) 2015. Available at https://ec.europa.eu/eurostat/statistics-explained/index.php?title=The_EU_ in_the_world__-_energy.

[7] Wikipedia Contributors, Tonne of oil equivalent, in Wikipedia, The Free Encyclopaedia 2018. Retrieved from https://en.wikipedia.org/w/index.php?title=Tonne_of_oil_ equivalent\&oldid=873843263.

[8] Eurostat Statistics Explained, Population and population change statistics (online) 2018. Available at https://ec.europa.eu/eurostat/statistics-explained/index.php/ Population_and_population_change_statistics.

[9] People > Population in 2015: Countries Compared (2015). Retrieved from https://www . nationmaster.com/country-info/stats/People/Population-in-2015.

[10] Worldometers, World Population by Year (online) 2019. Available at https://www . worldometers.info/world-population/world-population-by-year/. 
[11] Tikunov V. S., An Alternative View of the World (2000). Retrieved from https:// pasarelapr.com/detail/economic-map-of-the-world-27.html.

[12] World BANK, GDP per capita in US\$ (2017). Retrieved from https://ourworldindata. org/grapher/gdp-per-capita-in-us-dollar-world-bank?time=1960 . 2017.

[13] Watt J., Steam engine (Art, Architecture and Engineering Library) 1781.

[14] Wikipedia Contributors, Industrial Revolution, in Wikipedia, The Free Encyclopaedia (2019). Retrieved from https://en.wikipedia.org/w/index.php?title=Industrial_ Revolution\&oldid $=900847688$.

[15] Dampfmaschine/Dampfkraftmaschine, Steam engine/Steam power-Funktion, Aufbau \& Animation (Function, construction \& animation). Retrieved from https://www.k-wz. de/dampfmaschine/.

[16] Treading and Threshing, retrieved from http://mek.oszk.hu/02700/02790/html/61. html.

[17] Watson J., Farm mechanisation - Steam, wind, water and oil, Te Ara - the Encyclopedia of New Zealand. Retrieved from http://www.TeAra.govt.nz/en/photograph/18372/ steam-powered-threshing-machine.

[18] World population: Toward the next century, copyright by the Population Reference Bureau, 1994.

[19] Human population growth chart, World population growth charts - More than exponential 2009. Retrieved from http://www.subdude-site.com/WebPages_Local/Blog/ topics/environment/worldPopGrowth_charts/enviro_worldPopGrowth_charts.htm.

[20] Years of fossil fuel reserves left, BP Statistical Review of World Energy 2016. Retrieved from https://ourworldindata.org/grapher/years-of-fossil-fuel-reserves-left.

[21] IEA, EU Commission, VGB Powertech, Electricity generation facts and figures (2018).

[22] BP Statistical Review of World Energy (2019). Retrieved from https://www.bp.com/ content/dam/bp/business-sites/en/global/corporate/pdfs/energy-economics/ statistical-review/bp-stats-review-2019-full-report.pdf.

[23] Coal and lignite domestic consumption, Global Energy Statistical Yearbook (2019). Retrieved from https://yearbook.enerdata.net/coal-lignite/coal-worldconsumption-data.html.

[24] Nuclear Energy Agency and International Atomic Energy Agency, Uranium (2016). Retrieved from https://www.oecd-ilibrary.org/content/publication/ uranium-2016-en.

[25] Federal Institute for Geosciences and Natural Resources (BGR), Reserves, resources and availability of energy resources (2013). Retrieved from https://www.bgr. bund.de/EN/Themen/Energie/Downloads/energiestudie_2013_en.pdf?__blob= publicationFile\&v=2.

[26] World Energy Council, World energy resources (2016). p. 262. Retrieved from https://www . worldenergy .org/assets/images/imported/2016/10/World-EnergyResources-Full-report-2016.10.03.pdf.

[27] Federal Institute for Geosciences and Natural Resources (BGR), Data and developments concerning german and global energy supplies (2017) pp. 41-44. Retrieved from https://www.bgr.bund.de/EN/Themen/Energie/Downloads/energiestudie_2017_ en.pdf?_-_blob=publicationFile\&v=2.

[28] U.S. Department of Energy's (DOE) Environmental System Science Data Infrastructure for a VirTual Ecosystem (ESS-DIVE), VGB Powertech, Electricity generation facts and figures (2018).

[29] Paul Scherrer Institute (PSI) - Switzerland, ESU-services, VGB Powertech, Electricity generation facts and figures (2018). 
[30] Federal Ministry of Economic Affairs and Energy, Electricity Market of the Future-Facts and Figures (2014). Retrieved from https://www.bmwi.de/Redaktion/EN/ Artikel/Energy/electricity-market-of-the-future-facts-and-figures.html.

[31] Total Final Consumption (TFC) by source, Germany 1990-2016 (2016). Retrieved from https://www . iea.org/statistics/?country=GERMANY\&year=2016\&category=Energy\% 20 consumption\&indicator $=$ TFCbySource\&mode $=$ chart\&dataTable=BALANCES .

[32] Ziems C. and Meinke S., Kraftwerksbetrieb bei Einspeisung von Windparks und Photovoltaikanlagen (Power Plant Operation during Increased Energy Feed-in from Wind Parks and Photovoltaics), VGB Powertech, Techical Report No. 333 (2012).

[33] Weber H., Baskar P. and Ahmed N., Power system control with renewable sources, storages and power electronic converters, in 2018 IEEE International Conference on Industrial Technology (ICIT) 2018 (IEEE) 2018, pp. 1272-1278.

[34] Weber H., Baskar P. and Ahmed N., Nodal Voltage Angle Control of Power Systems with Renewable Sources, Storages and Power Electronic Converters, in 2018 International Conference on Smart Energy Systems and Technologies (SEST) (IEEE) 2018, pp. 1-6.

[35] Teichmann D., Arlt W., Wasserscheid P. and Freymann R., "A future energy supply based on liquid organic hydrogen carriers (LOHC)", Energy Environ. Sci., 4 (2011) 2767.

[36] Vasa stern color model, Wikimedia Commons, the free media repository (2015). Retrieved from https://commons.wikimedia.org/w/index.php?title=File:Vasa_stern_ color_model . jpg\&oldid=158708673.

[37] Voyage of the Vasa, Wikimedia Commons, the free media repository (2016). Retrieved from https://commons.wikimedia.org/w/index.php?title=File:Voyage_of_the_Vasa_ 2. svg\&oldid=189794035.

[38] KLASCHKA S., VASA's historic project management lesson (2012). Retrieved from https://orgchanger.com/2012/03/13/vasas-historic-project-management-lesson/. 